\title{
Ways to Overcome Poverty and Income Inequality in the Context of New Global Challenges: the Most Important Conclusions for Ukraine
}

\author{
Andrii Ramskyi (iD https://orcid.org/0000-0001-7368-697x \\ Doctor of Economics, Professor, Borys Grinchenko Kyiv University \\ Department of Finance and Economics, Kyiv, Ukraine \\ e-mail: a.ramskyi@kubg.edu.ua
}

\section{Abstract}

The article examines the risks of deepening poverty and income inequality that arise from global challenges of population aging, job losses due to shrinking sales markets, trade wars, long-term quarantine and compliance with the safe distancing of people as part of restrictive measures against the spread of COVID-19, the nature of employment (remote work, temporary reduction of labor migration), and other norms in the fight against the dangerous contagious disease. Given the facts that the prevention of spreading and localization of dangerous diseases, their treatment, and the rehabilitation of patients affect all segments of the population, have negative effects on all areas of people's lives and also add to the increase of socio-economic risks, including poverty and inequality, the study of this issue is extremely relevant. The financial implications of these challenges for many households lead to falling real incomes, and an increase in costs and debts, and their non-repayment, which generally cause sudden poverty and increasing inequality of income and property.

Purpose of the article: To investigate the risks of poverty, including sudden poverty, the inequality of household incomes amid the fight against the COVID-19 pandemic, and it identifies ways to overcome them.

Methods: A review of the scientific literature, a presentation of statistical data, and statistical research.

Findings \& Value added: As a result of research, a list of new risks of poverty and income inequality is outlined, and preliminary assessments of the consequences of the COVID-19 for households are summarized; signs of short-term loss are generalized; the solvency of households as a possible precondition for sudden poverty is evaluated; cross-country comparisons of poverty risk are made; the scheme of state aid 
to improve living standards of people during the outbreak of new dangerous diseases in the EU and Ukraine is generalized; ways to overcome poverty and income inequality are substantiated to restore the resilience of financially vulnerable households and ensuring the development of human capital.

Keywords: household finances, financial stability, struggle with poverty, inequality, labor migration, unemployment, COVID-19 pandemic, economic consequences of globalization, state support of households

JEL: J61, E24, I320, F650

\section{Introduction}

Overcoming poverty in all its forms is one of the main directions of achieving the Sustainable Development Goals. Between 1990 and 2019, the world made significant progress in ensuring people's well-being and reducing extreme poverty. In the EU countries, the share of people at risk of poverty and social exclusion decreased by 2.8 percentage points between 2013 and 2018. In 2018 it was 21.8\% (Eurostat 2020). The share of people whose daily consumption was less than 5.05 US dollars was reduced to $1.8 \%$.

Recent events show that, along with the fight against poverty and social inequality, the problem of reducing the risks of sudden poverty arising from global processes must be addressed, including the formation of financial stability of households to maintain solvency in times of crises and the sustainability of public finances, support of citizens, and realization of other social functions of the state.

Until recently, the most important global challenges have included population aging and growing demographic imbalances, trade wars, the rapid growth of the environmental crisis (with the intensification of related global problems - health care in the face of growing environmental pressures and global climate change; healthcare crises; the COVID-19 pandemic; instability of world food security), the scarcity of natural resources, including water resources, the deformation of market structures, and the crisis of capital investment efficiency in existing technological processes, production automation and digital technologies, international financial instability, and the problems of fictitious capital growth, among others (Sidenko 2014; Shang-Jin 2019; UN ESCAP 2019). These socio-economic and environmental problems pose risks to many countries around the world to achieve sustainable development and increase their competitiveness. They also exacerbate the problems of poverty and inequality in household incomes.

UN experts have found that poverty has a negative impact on people's health and life expectancy (due to the lack of quality drinking water, adequate medical services, and adequate nutrition) and limits educational opportunities for their children. The poverty of older people lays the groundwork for poverty for future generations. Insufficient investment in education and healthcare at the level of low-income households will nega- 
tively affect labor productivity, reduce the rate of human capital development, affect other factors of economic development and create risks for sustainable economic growth.

The unresolved nature of these problems was made worse by the emergence of a new global challenge - the spread of the life-threatening COVID-19 pandemic.

The aim of the article is to investigate the risks of poverty, including sudden poverty, inequality of household incomes amid the fight against the COVID-19 pandemic, as well as to identify ways to overcome them.

Achieving these goals necessitate the following tasks:

- to summarize existing approaches to poverty reduction in the framework of sustainable economic development;

- to reveal the directions of state regulation of the labor market, employment, reduction of unemployment, conditions of labor migration, personal income taxation, state support of corporations and households as prerequisites for reducing poverty and income inequality;

- to identify new risks of poverty and household income inequality arising from the COVID-19 pandemic;

- to analyze state aid schemes during the outbreak of the dangerous new disease and in the post-pandemic period to improve living standards and substantiate the directions of overcoming poverty and income inequality in Ukraine.

The impact of aggravated global risks on the financial stability of national economies and, accordingly, on households actualizes modern society's formation of a new institutional framework for sustainable economic growth and improving the welfare of the population.

\section{Literature review}

In the scientific literature, the problems of combatting poverty and the accelerated growth of income inequality are widely covered. But they remain relevant due to the emergence of new risks of socio-economic nature.

Research on poverty and inequality is carried out mainly in the following areas:

- developing theoretical foundations of these economic categories;

- defining tools for state regulation of the labor market, changes in the policy of income distribution, legal support of labor migration and spatial mobility of citizens, formation of social standards, personal income taxation, rules for indexation of employees' incomes in conditions of high inflation (Organiściak-Krzykowska 2017; Dluhopolskyi, Zatonatska, and Lvova 2019);

- state support: tax benefits for enterprises that employ people without work experience ("first job"), people with special needs (the disabled), workers of pre-retirement age; direct state support of enterprises during periods of financial and economic crises (in particular, for timely payment of wages and job retention); targeted assistance to low-income households, households with children, youth; 
- ensuring economic growth, which has a positive effect on increasing the income of most households (Kuznets 1955);

- providing equal access of households with different levels of income and financial opportunities to education and health services, which alleviates the problems of income inequality;

- investing in human development and insuring poor and vulnerable groups against emerging risks (Cruz et al. 2015).

The problems of ensuring the current liquidity of households remain relevant. Solving them will reduce the negative impact of the risks of financial losses from global challenges and prevent sudden poverty.

The psychological aspects of poverty (determining the level of poverty by different segments of the population, individual communities) were studied by Galbraith. It has been found that people suffer from poverty when their income, even if sufficient to survive, lags far behind that of the community as a whole. Then they cannot have what the large community considers the minimum necessary for decency, and they cannot completely avoid, therefore, the judgment of the community that they are poor (Galbraith 1958).

Kwiatkowski studied the behavior of labor markets in the EU countries during global crises. He found that the scale of adjustments in the labor market during a global crisis depends on several factors: the depth of demand shocks and the scale of adjustment of the volume of production, the degree of openness of the economy, labor productivity, the level of strict employment protection legislation, the current share of fixed-term employment contracts, as well as the possibility of the state regulator's influence on employers adjusting employees' wages and working hours (Kwiatkowski 2016).

He found that solving the problem of gender pay gaps has reduced inequality and increased household incomes (Cruz et al. 2015).

Kuznets studied the problems of income inequality in the twentieth century. He found that the income of the upper group of the population (about $7 \%$ of the total) tended to grow faster than the incomes (compensations) of other employees during periods of economic recovery.

With the slowdown in economic growth, the income of the upper group did not diminish, while $93 \%$ of employees (those with lower incomes than the higher group) had their wages and dividends significantly reduced (Kuznets 1955). Böhm -Bawerk argued that the level of increase in wages of the entrepreneurs (higher group) should be less than the growth of productivity because only part of the newly created value should be their reward (Böhm-Bawerk 1903).

Income and wealth inequality studies have been conducted from a global and historical perspective (e.g., Alvaredo et al. 2018). They showed that income and property inequality grew in different countries at different rates over time.

The growing inequality of income, wealth, and the welfare of households in different OECD countries over the last decade is explained by the differences between countries and regions. However, the standard of living of the poorest households has deteriorat- 
ed since the crisis, while that of high-income households has increased (Meeting of the OECD Council... 2017). This indicates that there are other reasons for the existence and deepening inequality of income and property of households in modern society, and its reduction requires the use of new institutional support.

The lack of effective tools to maintain the solvency of households in times of crisis or sudden poverty leads them to make irrational financial decisions, making them even poorer. Analysis of the liquidity survey showed that poor and vulnerable households all too often rely on expensive forms of credit (e.g., overdrafts) with high interest rates and fixed loan servicing costs (Cunha, Lambrecht, and Pawlina 2011).

Ukraine's fight against poverty and inequality is one of the government's key priorities. The "Sustainable Development Goals of Ukraine" program sets out the directions to gradually overcome poverty by eliminating its extreme forms. Libanova proposed some measures to fight income inequality in Ukraine, in particular, to change the procedure for taxing individuals' income by introducing a full-scale progressive scale of taxation, to complete the process of monetizing benefits, to change the practice of determining the cost of public services (medical, educational, etc.) and how they are paid (state budget, local budget, insurance funds, etc.), to improve the differentiation of social transfers based on working capacity, economic activity, and employment (stimulating the able-bodied population to the most active behavior in the labor market and in the economy as a whole); to introduce a system of control over costs and wealth in order to prevent large-scale unregistered income; to introduce a system of social elevators for low-income people, the disabled, children deprived of parental care, etc. (Libanova 2014).

The gradual introduction of European social living standards in Ukraine requires a significant strengthening of the economic base, fiscal expansion, and efficiency of social spending aimed at reducing the risks of poverty and income inequality, as well as building a reserve of household finances in the event of a crisis or a negative impact of global challenges.

\section{Reasons for the deepening risks of poverty in the context of global challenges}

On the one hand, the fight against the spread and consequences of the COVID-19 pandemic as one of the most significant global threats today has added to safer living conditions, proper diagnosis and treatment of the disease. On the other, it has worsened the general economic situation, increased unemployment and changed employment (remote work, forced reduction of working hours, unpaid leave, temporary suspension of labor migration), increasing the cost of households for prevention or treatment, and thus causing the deterioration of the financial situation of the vulnerable population. According to a new OECD report and unemployment statistics released in July 2020, women, young people, and low-income workers suffered the most during the quaran- 
tine period. The introduction and extension of quarantine, and the implementation of other precautionary measures had a negative impact on the labor market.

According to preliminary estimates, ${ }^{1}$ in the first half of 2020 , the unemployment rate surged by several percentage points compared to previous years. Its rise significantly exceeds the corresponding figures during the financial and economic crisis of 2008-2009. In some countries, in the first and second quarters of 2020, up to 10 times more working hours were lost compared to the first few months of the crisis of 2008-2009 (OECD 2020a).

The unemployment in OECD countries in April 2020 rose to 8.5\%, which is the highest unemployment rate in the last decade. In February 2020, it had been 5.2\%. The number of unemployed in OECD countries was about 54.5 million. Unemployment in OECD countries at the end of 2020 was expected to be $9.4 \%$ (in the optimistic scenario of the pandemic), which significantly exceeds the level of unemployment in periods of previous economic crises (OECD 2020b; 2020c). According to the pessimistic forecast, the unemployment rate is likely to be about $10 \%$, and with the start of the possible second wave of the spread of the virus and, accordingly, the strengthening of quarantine conditions - it may go up to 12\% (OECD 2020a; World Economic Outlook 2020).

It is projected that the average employment in 2020 will be $4.1 \%, 5$ percentage points lower than in 2019. The share of working people may return to the "pre-COVID-19 crisis" level only in late 2021/early 2022.

The self-employed, individual entrepreneurs, people on temporary or part-time contracts, and migrant workers have especially suffered the loss of work and income. Unemployment risks include young people who received their education this year and will need their "first job".

Well-thought-out ways out of the crisis of jobs, working conditions, and how they are paid for payment are becoming more important.

An express assessment ${ }^{2}$ of the impact of quarantine on employment (conducted by the Ukrainian Institute of Social Research named after Oleksandr Yaremenko, the Center for Social Monitoring together with the Department of Monitoring Research of Socio-Economic Transformations of the Institute of Economics and Forecasting of the National Academy of Sciences of Ukraine) showed that one third (35.6\%) of the economically active population of Ukraine during this period was excluded from the labor market. The most vulnerable were small businesses (four out of ten did not work)

1 A report on poverty and general well-being will be published in autumn 2020, which is expected to clarify, in particular, expectations of the unemployment rate by the end of 2020 , and the forecast for 2021 (Atamanov et al. 2020).

2 The survey of the adult population was conducted from 12 to 22 May 2020 in 24 regions of Ukraine and the city of Kyiv. A total of 2,058 respondents were interviewed via telephone. Standard deviations at a significant 95 percent and a ratio of variables from 0.1: 0.9 to 0.5 : 0.5 are $2.33-3.21$ percent. 
and the self-employed (one in three was unable to work). During quarantine, among the economically active population:

- $30.6 \%$ did not work; in particular: $19.2 \%$ were on forced leave (without pay); $7.7 \%$ were dismissed by the employer; $5.9 \%$ had restrictions on the activities of individual entrepreneurs; $8.8 \%$ lost their jobs; $6 \%$ were on paid annual leave;

- $66.5 \%$ worked; in particular: $42.2 \%$ worked at the same place according to the pre-quarantine schedule; $21.6 \%$ had reduced working hours; $4.3 \%$ found a job (another/temporary/additional) and worked; 20.8\% worked remotely.

At the same time, 8 out of 10 labor migrants lost their jobs; 4 out of 10 small-business entrepreneurs did not work. According to the survey, only a small proportion of employees' working conditions and wages did not change, and income remained at the pre-quarantine level (Express assessment... 2020).

Migration and labor processes were significantly changed at the beginning of quarantine, which led to job losses and the return of migrants to their home countries. Migrants' money transfers also decreased.

The intensification of migration of foreign labor from Central and Eastern European countries that belong to the European Union, i.e., the Czech Republic, Estonia, Lithuania, Latvia, Hungary, Poland, Slovenia, Slovakia, Bulgaria, and Romania, took place after the opening of the labor market by the EU-15 (Kwiatkowski 2010). Analysis of the size of migration outflows from Central and Eastern Europe (CEE) countries makes it possible to classify them into three groups: countries with high migration potential (Latvia, Lithuania, Romania), moderate migration potential (Hungary, Bulgaria, Poland, Estonia, Slovakia), and low migration potential (the Czech Republic, Slovenia) (Organiściak-Krzykowska 2017). As a result of employment abroad in 2004-2015, citizens of CEE transferred funds totaling 166.6 billion euros to their home countries. The ways in which this wealth is distributed at the individual level improve the living conditions of migrant household members and, indirectly, the socio-economic situation of every CEE country (Organiściak-Krzykowska 2017).

In Ukraine, the problem of the migrant remittance market is of particular interest. Ukraine is a powerful donor of international migrants and a recipient of money transfers - a relatively stable source of foreign exchange inflows into the country (Table 1). During the period 2017-2019, remittances from migrant workers increased by $\$ 2.7$ billion, and in 2019 they amounted to USD 11.9 billion. More than $30 \%$ of all money transfers came from Poland.

In 2019, revenues from the Czech Republic almost doubled (up to $9.3 \%$ of the total amount of remittances, or 1.1 billion US dollars).

In the wake of measures to combat the spread and consequences of the COVID-19 pandemic, the following processes took place: the return of migrant workers to their home countries and a reduction in employment of migrant workers who remained abroad due to the slowdown in economic activity in the recipient countries.

The forecast of money transfers to Ukraine for 2020 was reduced by 2.6 billion US dollars, or by $20 \%$ (down to $9-10$ billion US dollars) due to both the reduction in the 
number of migrants and reduced economic activity in the destination countries. At the same time, the impact of the current crisis is expected to be short-term, and from 2021 the growth of remittances will resume (Tokarchuk 2020).

Table 1. Volumes of private remittances to Ukraine (through official and unofficial channels of receipt)

\begin{tabular}{|c|c|c|c|c|c|c|}
\hline \multirow[b]{2}{*}{ Country } & \multicolumn{2}{|c|}{2017} & \multicolumn{2}{|c|}{2018} & \multicolumn{2}{|c|}{2019} \\
\hline & $\begin{array}{l}\text { USD } \\
\text { millions }\end{array}$ & $\begin{array}{c}\text { In } \% \text { of the } \\
\text { total } \\
\text { amount }\end{array}$ & $\begin{array}{l}\text { USD } \\
\text { millions }\end{array}$ & $\begin{array}{c}\text { In } \% \text { to the } \\
\text { total } \\
\text { amount }\end{array}$ & $\begin{array}{c}\text { USD } \\
\text { millions }\end{array}$ & $\begin{array}{c}\text { In } \% \text { to the } \\
\text { total } \\
\text { amount }\end{array}$ \\
\hline Receipts, incl.: & 9264 & 100 & 11111 & 100 & 11921 & 100 \\
\hline Poland & 3116 & 33.6 & 3649 & 32.8 & 3658 & 30.7 \\
\hline Czech Rep. & 435 & 4.7 & 846 & 7.6 & 1113 & 9.3 \\
\hline USA & 679 & 7.3 & 870 & 7.8 & 984 & 8.3 \\
\hline Italy & 447 & 4.8 & 492 & 4.4 & 498 & 4.2 \\
\hline Germany & 318 & 3.4 & 426 & 3.8 & 462 & 3.9 \\
\hline Cyprus & 285 & 3.1 & 341 & 3.1 & 391 & 3.3 \\
\hline
\end{tabular}

Source: National Bank of Ukraine 2020.

The current global crisis will have a greater negative impact on remittances than previous crises, as it is characterized by many countries closing their borders, which has an additional negative factor on labor migration.

The pandemic affected children's meals and school attendance. The introduction of quarantine interrupted the educational process around the world. From March to May 2020, more than $91 \%$ of students did not attend school, and from May to July 2020, it was $60-70 \%$ of students (United Nations Development Programme 2020).

In modeling the impact of forced school leaving on multidimensional poverty, according to the conservative scenario, a significant role is played by the decline in the quality of education and the risks of subsequent employment with high wages.

The COVID-19 pandemic has also disrupted lifestyles and food supply chains globally. According to the World Food Program, the number of people in dire need of food could increase to 130 million in 55 countries.

The above factors indicate a deepening of multidimensional poverty. The $2019 \mathrm{Mul}-$ tidimensional Poverty Index is calculated in 101 countries, where 5.7 billion people live. The index is able to assess the full spectrum of poverty, taking into account limitations in health, education, and living standards (including, in particular, nutrition, infant mortality, school life, school attendance, cooking fuel, sanitation, water, electricity, flooring, and property ownership). People who experience deprivation by at least a third of these weighted indicators fall into the category of the multidimensional poor (the percentage of the population with a deprivation rate of $20-33 \%$ ).

In 2019, 1.3 billion people fell into the category of multidimensional poverty, of which 886 million people - more than two-thirds - live in middle-income countries, and 440 million people live in low-income countries (United Nations Development Programme in Ukraine 2019). 
In poorer countries, a higher level of poverty is usually recorded, i.e., each poor person is restricted by more components of the index. Egypt and Paraguay were found to have similar Index values (approximately 0.019) and the proportion of the population in multidimensional poverty (5.2\% and 4.5\%, respectively), but inequality among the absolutely poor in Paraguay is much higher (fluctuations of 0.013) than in Egypt (0.004) (United Nations Development Programme in Ukraine 2019). At the same time, in Paraguay, the largest share of the population vulnerable to multidimensional poverty was $7.2 \%$ (Table 2).

Table 2. The multidimensional poverty index in some countries for 2007-2018

\begin{tabular}{|c|c|c|c|c|c|c|}
\hline \multirow[b]{2}{*}{$\begin{array}{l}\text { Countries, } \\
\text { Group } \\
\text { of countries }\end{array}$} & \multirow[b]{2}{*}{$\begin{array}{l}\text { Multi-dimen- } \\
\text { sional pover- } \\
\text { ty index }\end{array}$} & \multirow{2}{*}{$\begin{array}{l}\text { Population } \\
\text { in multi- } \\
\text {-dimensional } \\
\text { poverty, \% }\end{array}$} & \multirow{2}{*}{$\begin{array}{l}\text { Population } \\
\text { vulnerable } \\
\text { to multi- } \\
\text {-dimensional } \\
\text { poverty, \% }\end{array}$} & \multirow{2}{*}{$\begin{array}{c}\text { Population } \\
\text { living below } \\
\text { the poverty } \\
\text { line (national } \\
\text { assessment), } \\
\%\end{array}$} & \multicolumn{2}{|c|}{$\begin{array}{l}\text { Components } \\
\text { of the index }\end{array}$} \\
\hline & & & & & $\begin{array}{l}\text { Health- } \\
\text { care, \% }\end{array}$ & $\begin{array}{l}\text { Living } \\
\text { condi- } \\
\text { tions, \% }\end{array}$ \\
\hline Albania & 0.003 & 0.7 & 5.0 & 14.3 & 28.3 & 16.7 \\
\hline Armenia & 0.001 & 0.2 & 2.7 & 25.7 & 33.1 & 30.1 \\
\hline Brazil & 0.016 & 3.8 & 6.2 & 26.5 & 49.8 & 27.3 \\
\hline Egypt & 0.019 & 5.2 & 6.1 & 27.8 & 39.8 & 7.0 \\
\hline Kazakhstan & 0.002 & 0.5 & 1.8 & 2.5 & 90.4 & 6.4 \\
\hline Kyrgyzstan & 0.008 & 2.3 & 8.3 & 25.6 & 52.8 & 34.3 \\
\hline Nigeria & 0.291 & 51.4 & 16.8 & 46.0 & 27.0 & 40.8 \\
\hline Pakistan & 0.198 & 38.3 & 12.9 & 24.3 & 27.6 & 31.1 \\
\hline Paraguay & 0.019 & 4.5 & 7.2 & 26.4 & 14.3 & 46.8 \\
\hline Tajikistan & 0.029 & 7.4 & 20.1 & 31.3 & 47.8 & 25.8 \\
\hline Turkmenistan & 0.001 & 0.4 & 2.4 & - & 88.0 & 7.6 \\
\hline Ukraine & 0.001 & 0.2 & 0.4 & 2.4 & 59.7 & 11.5 \\
\hline $\begin{array}{l}\text { Developing } \\
\text { countries }\end{array}$ & 0.114 & 23.1 & 15.3 & 21.3 & 25.8 & 44.7 \\
\hline
\end{tabular}

Source: United Nations Development Programme in Ukraine 2019.

In Ukraine, the Multidimensional Poverty Index is much lower (0.001) than the average in developing economies (0.114). Also, only a small proportion of the population is vulnerable to multidimensional poverty $(0.4 \%)$. More than a million people live below the poverty line (2.4\%). At the same time, more attention needs to be paid to human health $(59.7 \%$ is an indicator that is almost twice as high as the average in the group of developing countries), which means that there is a need to review and evaluate health care reforms in Ukraine. In Ukraine, health care expenditures in 2019 amounted to $3.2 \%$ of GDP, which is more than twice less than in the EU.

In 2020, the multidimensional poverty index in Ukraine may increase by $12-14$ points in our pessimistic scenario.

In Nigeria and Pakistan, the population in multidimensional poverty is $51.4 \%$ and $38.3 \%$, respectively; however, the proportion of the population vulnerable to poverty 
was $16.8 \%$ and $12.9 \%$, respectively, which is 3.3 and 7.2 percentage points lower, respectively, for the indicator of Tajikistan. This indicates the continuation of a policy narrowly aimed at groups of poor people. Given that the needs of the most and least disadvantaged can be very different, targeted assistance should be developed. At the same time, the average level of household wealth also differs significantly in different countries (the gap can be more than 23 times).

Households are the richest in countries such as Luxembourg and Belgium (OECD Wealth Distribution 2020). However, the average life satisfaction of households in OECD countries increased slightly compared to 2013 (Eurostat, Income...n.d.).

Poverty is a complex phenomenon. The correlation between economic inequality and the Multidimensional Poverty Index (as measured by the Gini coefficient) is insignificant (United Nations Development Programme in Ukraine 2019). Therefore, it is expedient to develop ways of overcoming poverty separately from the directions of reducing income inequality. What is unifying is that the risks of poverty and income inequality have the greatest impact on people with low incomes and insufficient solvency.

New risks of poverty (along with existing ones, including insufficient income, the social burden on households, which include young children, the unemployed, the disabled, or the elderly in need of care) may include:

- forced self-isolation of household members living with a patient with the COVID-19 (without monetary compensation of income), as well as people who are subject to isolation due to the limitations of crossing the borders with "red zone" countries;

- forced leave to look after young children and primary school pupils for the period of quarantine in kindergartens and schools;

- reduced income when working conditions change (reduced working hours, teleworking);

- a significant increase in transport costs for people working in strategic enterprises in the absence of public transport;

- increased costs of medical services and medicines due to COVID-19.

These risks lead to a short-term loss of solvency of households, and in the case of their financial vulnerability and lack of an adequate level of sustainability of household finances, they create the preconditions for sudden poverty.

\section{Problems of household income inequality in modern conditions}

Inequality mainly arises in the distribution of individual labor incomes among the working-age population, different levels of social burden on households (which varies significantly depending on its composition, number of employees, and the presence of family members in need of third-party care), as well as income differentiation from capital. 
In the last decade, income inequality has been growing in almost all countries, but at different rates. Since 1980, income inequality has grown rapidly in North America and Asia and moderately in Europe (Alvaredo et al. 2018). On average, among the OECD countries, the richest $20 \%$ earn 5.4 times more than the poorest $20 \%$ (OECD Wealth Distribution 2020). On average, the richest $10 \%$ own more than half of the total household wealth.

The interactive computing tool, PovcalNet, is used to assess household income inequality and to make cross-country comparisons of welfare, inequality, and poverty (it contains more than 1,900 surveys from 166 countries, covering $97.5 \%$ of the world's population; data available in PovcalNet are highly standardized). According to this database, it is possible to assess the level of risk of poverty in individual European countries for the formation or adjustment of public policy in the field of poverty reduction (Table 3).

Table 3. Poverty risk in some European countries in 2016-2018

\begin{tabular}{|l|c|c|c|c|c|c|}
\hline $\begin{array}{c}\text { Country, } \\
\text { Group } \\
\text { of countries }\end{array}$ & $\begin{array}{c}\text { Gross disposable } \\
\text { income of the } \\
\text { population, billion } \\
\text { euros }\end{array}$ & $\begin{array}{c}\text { Poverty } \\
\text { gap } \\
\text { (SPG)* }\end{array}$ & $\begin{array}{c}\text { Poverty } \\
\text { index } \\
\text { Wt** }\end{array}$ & $\begin{array}{c}\text { Gini } \\
\text { index } \\
* * *\end{array}$ & $\begin{array}{c}\text { Average } \\
\text { monthly } \\
\text { income, } \$\end{array}$ & $\begin{array}{c}\text { The } \\
\text { population } \\
\text { with signs } \\
\text { of poverty, } \\
\text { in thousands }\end{array}$ \\
\hline EU-27 & $9,781.2$ & $\ldots$ & $\ldots$ & $\ldots$ & $\ldots$ & 73,796 \\
\hline Belgium & 334.9 & 0.09 & 0.09 & 27.37 & $1,344.53$ & 1,844 \\
\hline Czech Rep. & 131.3 & 0 & 0 & 24.85 & 811.25 & 996 \\
\hline Denmark & 200.0 & 0.07 & 0.18 & 28.75 & 1420.98 & 728 \\
\hline Germany & $2,508.7$ & 0 & 0 & 31.87 & 1419.3 & 13,048 \\
\hline Estonia & 17.2 & 0.14 & 0.33 & 30.36 & 846.05 & 286 \\
\hline Ireland & 135.7 & 0.08 & 0.05 & 32.81 & 1217.77 & 726 \\
\hline Greece & 134.5 & 0.31 & 0.57 & 34.35 & 585.56 & 1,954 \\
\hline Spain & 879.2 & 0.5 & 0.36 & 34.65 & 996.52 & 9,950 \\
\hline France & $1,832.7$ & 0 & 0 & 31.63 & $1,364.45$ & 8,497 \\
\hline Croatia & 37.7 & 0.26 & 0.28 & 30.35 & 581.36 & 783 \\
\hline Italy & $1,370.9$ & 1.01 & 0.99 & 35.93 & $1,083.41$ & 12,229 \\
\hline Cyprus & 15.4 & 0 & 0.01 & 31.42 & $1,159.96$ & 132 \\
\hline Latvia & 20.3 & 0.2 & 0.47 & 35.57 & 659.63 & 446 \\
\hline Lithuania & 31.6 & 0.75 & 0.55 & 37.29 & 680.29 & 644 \\
\hline Luxemburg & 28.7 & 0.13 & 0.09 & 34.9 & $2,171.98$ & 106 \\
\hline Hungary & 86.6 & 0.27 & 0.65 & 30.58 & 637.08 & 1,227 \\
\hline Holland & 510.0 & 0.04 & 0.11 & 28.54 & $1,438.84$ & 2,247 \\
\hline Austria & 275.3 & 0.21 & 0.51 & 29.74 & $1,540.74$ & 1,238 \\
\hline Poland & 338.7 & 0.15 & 0.22 & 29.69 & 724.48 & 5,472 \\
\hline Portugal & 160.5 & 0.13 & 0.36 & 33.8 & 689.78 & 1,777 \\
\hline Romania & 144.3 & 0.85 & 1.9 & 36.02 & 392.64 & 4,603 \\
\hline Slovenia & 32.3 & 0 & 0 & 24.22 & 984.32 & 268 \\
\hline Slovakia & 62.5 & 1.08 & 0.33 & 25.17 & 652.66 & 655 \\
\hline
\end{tabular}


Table 3. (continued)

\begin{tabular}{|l|c|c|c|c|c|c|}
\hline $\begin{array}{c}\text { Country, } \\
\text { Group } \\
\text { of countries }\end{array}$ & $\begin{array}{c}\text { Gross disposable } \\
\text { income of the } \\
\text { population, billion } \\
\text { euros }\end{array}$ & $\begin{array}{c}\text { Poverty } \\
\text { gap } \\
\text { (SPG)* }\end{array}$ & $\begin{array}{c}\text { Poverty } \\
\text { index } \\
\mathbf{W t}^{* *}\end{array}$ & $\begin{array}{c}\text { Gini } \\
\text { index } \\
* * *\end{array}$ & $\begin{array}{c}\text { Average } \\
\text { monthly } \\
\text { income, \$ }\end{array}$ & $\begin{array}{c}\text { The } \\
\text { population } \\
\text { with signs } \\
\text { of poverty, } \\
\text { in thousands }\end{array}$ \\
\hline Finland & 169.1 & 0.06 & 0.12 & 27.38 & $1,350.88$ & 652 \\
\hline Sweden & 323.6 & 0.11 & 0.19 & 28.77 & $1,455.22$ & 1,660 \\
\hline $\begin{array}{l}\text { United King- } \\
\text { dom }\end{array}$ & $1,933.4$ & 0.13 & 0.06 & 34.78 & $1,265.29$ & 12,168 \\
\hline Norway & 232.8 & 0.16 & 0.8 & 26.99 & $1,893.97$ & 682 \\
\hline Switzerland & 404.8 & 0 & 0 & 32.68 & $1,709.01$ & 1,217 \\
\hline Ukraine & 79.9 & 0 & 0 & 26.07 & 355.13 & $1,163^{* * *}$ \\
\hline
\end{tabular}

Notes: * - square poverty gap (SPG), defined as the average income deficit below the poverty line;

** - poverty index $W$ is the average value of the proportional poverty gap; Gini index - a measure of inequality between 0 (everyone has the same income) and 100 (the richest person has all the income);

*** - model calculations of the author taking into account the level of the shadow economy. Source: State Statistics Service of Ukraine 2018; Data from The World Bank 2020; Eurostat, Households... n.d.

In the studied group of countries, the highest value of the Gini index in 2016-2018 was observed in Lithuania (37.29), Romania (36.02), and Italy (35.93). If the Gini index in each country decreases by $1 \%$ per year, the global poverty rate may fall to about $5.4 \%$ in 2030 , equivalent to 100 million fewer people living in poverty (Lakner et al. 2019). In 2017-2018, the risk of poverty decreased in most EU countries, but in countries such as Estonia, Sweden, and the Czech Republic, there was an increase in the level of risk (0.9 percentage points, 1.1 percentage points, 0.3 percentage points respectively). At the same time, more than a third of people in the OECD are at risk of falling into poverty (OECD Wealth Distribution 2020). This can be explained by the lack of proper sustainability of household finances and the vulnerability to wage cuts, the main source of income. Analysis of the indicator that refers to the number of people with signs of poverty showed a dependence on the indicator referring to gross disposable income. The dependence density is $\mathrm{R} 2=0.8353$, where $\mathrm{y}$ - gross disposable income of the population, and $\mathrm{x}$ - the number of people with signs of poverty.

The financial implications of the Corona crisis show that global challenges have a significant impact on household well-being, but household inequality is not diminishing. In European OECD countries, on average, one in five households faces deteriorating solvency (Eurostat, Income... n.d.).

Modern Ukrainian society is not just deeply stratified, it is polarized. At one end of the scale, a relatively small (no more than $5-7 \%$ ) group of the affluent population is concentrated, and at the other, at least a quarter of the population is barely surviving (Libanova 2014). The origins of modern inequality, at least in the public consciousness, are mainly due to non-compliance with the law and shadow activities. The rapid stratification of Ukrainian society took place in the early 1990s, when abrupt changes in economic conditions and large-scale privatization led to a concentration of resources and nation- 
al wealth in the hands of a relatively small group of people under the conditions of impoverishment and low-paid employment of the rest of the population (Libanova 2014). For the wealthiest segments of Ukraine's population, the growth rate of income between 2000 and 2019, regardless of the economic recovery, was much higher than for the average citizen. Unjustifiably high incomes are received by heads of state-owned enterprises, enterprises classified as natural monopolies, as well as companies in which the state has a share of the authorized capital. Against the background of deteriorating financial conditions of these enterprises, such payments lead to increased costs and demand for higher tariffs and prices. Managers' incomes differ from the average salary by tens of times. During the Corona crisis, this causes social tension. In Ukraine, the share of the population with per capita equivalent total income per month, below 2018's actual subsistence level, was $43.2 \%$, which is 13.2 percentage points more than the expected result of $30 \%$.

New risks to income inequality include declining incomes of the working population at a faster rate than increasing financial and other passive household incomes.

In general, the pandemic has a strong negative impact on low-income households worldwide, which can significantly increase inequality. In 2020 , more than $90 \%$ of developing countries are likely to have negative per capita income growth rates (Gaspar, Lam, and Raissi 2020).

Public investment in education, health, and the environment are needed both to combat existing inequality and to prevent its growth in the future (Alvaredo et al. 2018).

\section{State support}

Many governments, through state support mechanisms, take measures to reduce the negative effects on households, combining support for labor markets and the corporate sector to halt rising unemployment. Measures vary from country to country, but in some cases, they include assistance to households and businesses. Business assistance is provided in the following three main forms: state guarantees; low interest rate loans and other forms of debt financing, including convertible bonds; and the direct introduction of equity by the state. The analysis showed that without any government intervention, $20 \%$ of the firms surveyed (in the intersectoral sample of almost a million firms operating in 16 European countries) would lose liquidity in one month (Gurría 2020). Up to $38 \%$ of firms could lose liquidity within three months.

As a result of the pandemic, the global economy is projected to shrink to $-4.9 \%$ in 2020, which is significantly worse than during the 2008-2009 financial crisis.

In emerging market countries, budgetary responses to the pandemic are now estimated at an average of 5\% of GDP, which is significant but less than in developed economies. However, the budget deficit is projected to increase sharply in 2020 to an average of $10.5 \%$ of GDP, more than double the previous year. As many low-income countries have pursued policies of fiscal consolidation, rising health care spending, and social 
protection, there will be no fiscal risks. In countries (particularly in Ukraine), where public finances have been consolidated through reduced social spending and funding for health facilities, it may lead to public investment and increased current spending on health care in the treatment of patients with the COVID-19 pandemic.

Some countries have taken budgetary measures to contain the pandemic and reduce its damage to the economy. The tools of the social protection system also stabilize income and consumption (Gaspar, Lam, and Raissi 2020).

State aid in EU countries is provided in accordance with the provisions of the Treaty on the Functioning of the European Union. Funding of more than $€ 22.5$ billion is given to state aid measures taken under Article 107 (2)b TFEU, including assistance to deal with damage caused by natural disasters or emergencies. More than $€ 114$ billion has been allocated to meet the objectives set out in Article 107 (3)b TFEU - assistance to facilitate the implementation of an important project of common European interest or to remedy serious disturbances in a Member State's economy. About $€ 530$ billion has been allocated to state aid measures taken under Article 107 (3)c TFEU - aid to facilitate the development of certain economic activities or certain economic areas, where such aid does not adversely affect trading conditions to an extent contrary to the common interest (European Commission 2021).

The generalized state aid scheme during the outbreak of new dangerous diseases in the EU is aimed at improving the living standards of the population and provides funding for measures to eliminate the consequences of the prevention, spread, and localization of the disease, the treatment and rehabilitation of patients, research, development, and testing of new drugs for dangerous diseases, vaccine development, insurance of medical workers who directly provide medical services; to eliminate serious disturbances in the economy through targeted assistance to households and enterprises; to promote the development of certain economic activities or certain economic areas.

In Ukraine, the Ministry of Finance has established the Fund for Combatting COVID-19. The activities of the Fund and the allocation of funds are regulated by resolutions of the Cabinet of Ministers of Ukraine, in particular: Resolution of the Cabinet of Ministers of April 22, 2020, № 302 “On approval of the Procedure for using the Fund for Acute Respiratory Disease COVID-19 caused by SARS-CoV-2 coronavirus and its consequences"; Resolution of the Cabinet of Ministers of April 27, 2020, № 308 "On the allocation of funds for the provision of financial assistance to the Fund of Compulsory State Social Insurance in the Event of Unemployment"; Resolution of the Cabinet of Ministers of April 29, 2020, № 354 “On the allocation of funds for the purchase of ventilators."

As of July 31, 2020, UAH 65.95 billion (or 1.7\% of GDP, which is almost three times less than the average in the EU countries) was allocated for the measures provided by the regulations of Ukraine (Table 4). At the same time, more than half of all funds were allocated for the construction and reconstruction of roads of state importance. In our opinion, funding for these works should not have been provided by the COVID-19 Anti-Crisis Fund. 
Ways to Overcome Poverty and Income Inequality in the Context of New Global Challenges...

Table 4. Use of the Fund for Combatting COVID-19 as of 31.07.2020

\begin{tabular}{|c|c|c|c|c|c|}
\hline $\begin{array}{l}\text { No } \\
\text { s/n }\end{array}$ & Direction & Measures & $\begin{array}{l}\text { Funds } \\
\text { allocated, } \\
\text { UAH } \\
\text { millions }\end{array}$ & $\begin{array}{l}\text { Cash } \\
\text { expenditures, } \\
\text { UAH millions }\end{array}$ & $\begin{array}{l}\text { Spent } \\
\text { from the } \\
\text { allocated } \\
\text { sum, \% }\end{array}$ \\
\hline 1 & $\begin{array}{l}\text { Cash assistance } \\
\text { to citizens }\end{array}$ & $\begin{array}{l}\text { Cash assistance to children } \\
\text { of entrepreneurs } \\
\text { (individuals) }\end{array}$ & 1155.0 & 549.7 & 1.7 \\
\hline 2 & Social support & $\begin{array}{l}\text { Financial assistance to the } \\
\text { Unemployment Insurance } \\
\text { Fund }\end{array}$ & 6972.5 & 6079.4 & 87.2 \\
\hline 3 & Social support & $\begin{array}{l}\text { Financial assistance to the } \\
\text { Social Insurance Fund (incl. } \\
\text { for the payment of sick } \\
\text { leave) }\end{array}$ & 2512.1 & 1538.2 & 61.2 \\
\hline 4 & $\begin{array}{l}\text { Measures to prevent } \\
\text { outbreaks } \\
\text { of COVID-19. }\end{array}$ & Purchase of ventilators & 100 & 0 & 0 \\
\hline 5 & $\begin{array}{l}\text { Measures to prevent } \\
\text { outbreaks of COVID-19 }\end{array}$ & $\begin{array}{l}\text { Provision of laboratories } \\
\text { of Min. of Health, and } \\
\text { purchase of personal } \\
\text { protective equipment }\end{array}$ & 2990 & 339.1 & 11.3 \\
\hline 6 & $\begin{array}{l}\text { Measures to prevent } \\
\text { outbreaks of COVID-19 }\end{array}$ & $\begin{array}{l}\text { Prevention of COVID-19 } \\
\text { in institutions of the State } \\
\text { Penitentiary Service }\end{array}$ & 23.7 & 5.9 & 24.7 \\
\hline 7 & $\begin{array}{l}\text { Measures to prevent } \\
\text { outbreaks of COVID-19 }\end{array}$ & $\begin{array}{l}\text { Reimbursement for } \\
\text { Independent External } \\
\text { Evaluation trials in } 2020\end{array}$ & 52.5 & 52.5 & 100 \\
\hline 8 & $\begin{array}{l}\text { Measures to prevent } \\
\text { outbreaks of COVID-19 }\end{array}$ & $\begin{array}{l}\text { Construction, } \\
\text { reconstruction, and repairs } \\
\text { of state roads }\end{array}$ & 35000 & 3505.7 & 10 \\
\hline 9 & $\begin{array}{l}\text { Measures to prevent } \\
\text { outbreaks of COVID-19 }\end{array}$ & $\begin{array}{l}\text { Equipment for reception } \\
\text { departments of support } \\
\text { hospitals }\end{array}$ & 5300 & 0 & 0 \\
\hline 10 & $\begin{array}{l}\text { Measures to prevent } \\
\text { outbreaks of COVID-19 }\end{array}$ & $\begin{array}{l}\text { Construction and repair } \\
\text { of reception departments } \\
\text { of support hospitals }\end{array}$ & 1680 & 0 & 0 \\
\hline 11 & $\begin{array}{l}\text { Measures to prevent } \\
\text { outbreaks of COVID-19 }\end{array}$ & $\begin{array}{l}\text { Purchase of equipment, } \\
\text { personal protective } \\
\text { equipment }\end{array}$ & 41.2 & 0 & 0 \\
\hline 12 & $\begin{array}{l}\text { Measures to prevent } \\
\text { outbreaks of COVID-19 }\end{array}$ & $\begin{array}{l}\text { State support in the field } \\
\text { of culture, tourism, and } \\
\text { creative industries }\end{array}$ & 1000 & 0 & 0 \\
\hline 13 & $\begin{array}{l}\text { Surcharges } \\
\text { for employees } \\
\text { on liquidation } \\
\text { of COVID-19 }\end{array}$ & $\begin{array}{l}\text { Surcharges for the } \\
\text { members of the military, } \\
\text { National Guard, State } \\
\text { Border Service, and police } \\
\text { of the Ministry of Internal } \\
\text { Affairs }\end{array}$ & 2530 & 1845.1 & 72.9 \\
\hline
\end{tabular}


Table 4. (continued)

\begin{tabular}{|c|c|c|c|c|c|}
\hline $\begin{array}{l}\text { No } \\
\text { s/n }\end{array}$ & Direction & Measures & $\begin{array}{l}\text { Funds } \\
\text { allocated, } \\
\text { UAH } \\
\text { millions }\end{array}$ & $\begin{array}{l}\text { Cash } \\
\text { expenditures, } \\
\text { UAH millions }\end{array}$ & $\begin{array}{l}\text { Spent } \\
\text { from the } \\
\text { allocated } \\
\text { sum, \% }\end{array}$ \\
\hline 14 & $\begin{array}{l}\text { Surcharges } \\
\text { for employees } \\
\text { on liquidation } \\
\text { of COVID-19 }\end{array}$ & $\begin{array}{l}\text { Surcharges for medical } \\
\text { workers in health care } \\
\text { facilities of the Ministry } \\
\text { of Internal Affairs }\end{array}$ & 171.1 & 91.2 & 19.1 \\
\hline 15 & $\begin{array}{l}\text { Surcharges } \\
\text { for employees } \\
\text { on liquidation } \\
\text { of COVID-19 }\end{array}$ & $\begin{array}{l}\text { Increased allowances and } \\
\text { surcharges for medical } \\
\text { workers }\end{array}$ & 5955.4 & 0 & 0 \\
\hline 16 & $\begin{array}{l}\text { Restoration of state } \\
\text { budget expenditures }\end{array}$ & $\begin{array}{l}\text { Partial recovery } \\
\text { of expenditures in the field } \\
\text { of physical culture and } \\
\text { sports }\end{array}$ & 475.8 & 0 & 0 \\
\hline & & Total & $65,959.3$ & $14,006.6$ & 21.2 \\
\hline
\end{tabular}

Source: Minfin systematizes information... 2020.

The directions cited in Table 4 were financed only by $21.2 \%$ (or $0.35 \%$ of GDP), which indicates funds were diverted from their intended purpose or misused. Under some programs, no funding has started at all: the purchase of ventilators, increased allowances and surcharges for medical workers, the purchase of equipment for reception departments of support hospitals, etc. In this regard, it is proposed to strengthen state financial control by the Accounting Chamber of Ukraine, state internal audit in the Ministry of Finance of Ukraine and introduce monitoring of funding for these areas by the Ministry of Social Policy of Ukraine.

\section{Conclusions and suggestions}

Summing up the analysis of the problem of poverty and income inequality in the context of new global challenges and making the important conclusions for Ukraine, it should be noted:

1. The tendency to reduce extreme poverty, which has become entrenched in modern society over the past decade, has been reversed, exacerbating the problems of poverty under the influence of the spread of the disease dangerous to humans, i.e., the COVID-19 pandemic.

2. New risks of poverty both in Ukraine and around the world may include forced self-isolation of people (without monetary compensation of income), forced unpaid leave to look after young children and primary school pupils for the period of quarantine in kindergartens and schools; reduced income when changing working conditions (reduced working hours, teleworking); increased expendi- 
tures on medical services, medicines through COVID-19 and other unforeseen expenses by households.

3. The generalized scheme of state aid during the outbreak of the new dangerous disease should be aimed at improving the living standards of the population and provide funding for measures to eliminate the effects of COVID-19 and the insurance of health workers who directly provide medical services; eliminating serious disturbances in the economy through targeted assistance to households and enterprises; promoting the development of certain economic activities or certain economic areas.

4. The main ways to overcome poverty and income inequality to restore the resilience of financially vulnerable Ukrainian households and ensure the development of human capital can include:

- expanding the list of unemployment benefits, in particular, for payments for reduced working hours, unpaid leave, early termination of the contract for the quarantine period, transition to temporary work with lower wages;

- introducing paid leave for one of the parents to look after young children and primary school students for the period of quarantine in kindergartens and schools;

- simplifying the procedure for obtaining long-term sick leave for the treatment and rehabilitation of patients, as well as legislative consolidation of sick pay to isolate all family members living with the patient during outbreaks of dangerous diseases, including the COVID-19 pandemic;

- introducing incentives for employers to set up safe work and create new jobs.

In these cases, a simplified form of state support for the sustainability of Ukrainian household finances may include short-term, interest-free loans and direct grants in the amount of the minimum wage. Also, in such situations, a non-standard form of state communication should be used, and the legislative framework, in particular the Labor Code of Ukraine, should be amended.

5. The deepening impact of global risks on the financial sustainability of national economies and, accordingly, on households actualizes the formation by modern society of a new institutional framework for sustainable economic growth and improves the welfare of the population.

\section{References}

Alvaredo, F., Chancel, L., Piketty, T., Saez, E., Zucman, G. (2018), World Inequality Report 2018. Executive Summary, https://wir2018.wid.world/files/download/wir20 18-summary-english.pdf (accessed: 5.03.2020).

Atamanov, A., Castaneda Aguilar, R.A., Fujs, T.H.M.J., Dewina, R., Diaz-Bonilla, C., Mahler, D.G., Jolliffe, D., Lakner, C., Matytsin, M., Montes, J., Moreno Herrera, L.L., Mungai, R., Newhouse, D., Nguyen, M.C., Parada Gomez Urquiza, F.J., Silwal, A.R., 
Sanchez Castro, D.M., Schoch, M., Vargas Mogollon, D.L., Viveros Mendoza, M.C., Yang, J., Yoshida, N., Wum, H. (2020), Global Poverty Monitoring Technical Note. March 2020 PovcalNet Updatem http://documents1.worldbank.org/curated/en/407 961584980637951/pdf/March-2020-PovcalNet-Update-Whats-New.pdf (accessed: 3.08.2020).

Böhm-Bawerk, E. (1903), Foundations of the theory of the value of economic benefits, The MacMillan Co., London.

Consolidated version of the Treaty on the Functioning of the European Union (2008), Part Three: Union Policies and Internal Actions. Title VII: Common Rules on Competition, Taxation and Approximation of Laws. Chapter 1: Rules on competition. Section 2: Aids granted by States, Article 107, https://eur-lex.europa.eu/legal-content /EN/ALL/?uri=CELEX:12008E107 (accessed: 5.03.2020).

Cruz, M., Foster, J., Quillin, B., Schellekens, P. (2015), Ending Extreme Poverty and Sharing Prosperity: Progress and Policies, Policy Research Notes No. 101740, from The World Bank, https://econpapers.repec.org/paper/wbkwbkprn/101740.htm (accessed: 5.03.2020).

Cunha, M.R., Lambrecht, B.M., Pawlina, G. (2011), Household Liquidity and Incremental Financing Decisions: Theory and Evidence, "Journal of Business Finance \& Accounting”, 38 (7-8), pp. 1016-1052, https://doi.org/10.1111/j.1468-5957.2011.02248.x

Dluhopolskyi, O., Zatonatska, T., Lvova, E. (2019), Regulations for Returning Labour Migrants to Ukraine: International Background and National Limitations, "Comparative Economic Research. Centran and Eastern Europe”, 22 (3), pp. 45-64, https:// doi.org/10.2478/cer-2019-0022

European Commission (2021), Coronavirus Outbreak List of Member State Measures approved under Articles 107 (2)b, 107 (3)b and 107 (3)c TFEU and under the State Aid Temporary Framework, https://ec.europa.eu/competition/state_aid/what_is_new /State_aid_decisions_TF_and_107_2b_107_3b_107_3c.pdf (accessed: 5.03.2020).

Eurostat (n.d.), Households - statistics on disposable income, saving and investment, https://ec.europa.eu/eurostat/data/database (accessed: 3.08.2020).

Eurostat (n.d.), Income and Living Conditions (EU-SILC), https://ec.europa.eu/eurostat /web/income-and-living-conditions/data/database (accessed: 3.08.2020).

Eurostat (2020), People at risk of poverty or social exclusion, https://ec.europa.eu/euros tat/databrowser/view/sdg_01_10/default/table?lang=en (accessed: 3.08.2020).

Express assessment of the impact of quarantine on employment, The Ukrainian Institute of Social Research named after O. Yaremenko, Center for Social Monitoring, in conjunction with the Department of Monitoring Research of Socio-Economic Transformations of the Institute for Economics and Forecasting of the NAS of Ukraine, http://ief.org.ua/?attachment_id=8612 (accessed: 3.08.2020).

Galbraith, J.K. (1958), The Affluent Society, Houghton Mifflin, Boston, http://pinguet .free.fr/affluent58.pdf (accessed: 5.03.2020).

Gaspar, V., Lam, W.R., Raissi, M. (2020), Fiscal Policies to Contain the Damage from COVID-19, https://blogs.imf.org/2020/04/15/fiscal-policies-to-contain-the-damag e-from-covid-19/ (accessed: 3.08.2020). 
Gurría, A. (2020), Shaping government interventions for a faster and more resilient economic recovery, https://www.oecd.org/competition/oecd-sg-at-session-on-competi tion-policy-in-time-of-covid19-june-2020.htm (accessed: 3.08.2020).

Kuznets, S. (1955), Economic Growth and Income Inequality, “The American Economic Review", 45 (1), pp. 1-28.

Kwiatkowski, E. (2010), Migracje zagraniczne Polaków i ich konsekwencje makroekonomiczne, [in:] S. Bukowski (ed.), Globalizacja i integracja regionalna a wzrost gospodarczy, CeDeWu, Warszawa, pp. 203-212.

Kwiatkowski, E. (2016), Why have labour markets reacted to the global crisis in different ways?, "Comparative Economic Research. Central and Eastrern Europe", 19 (4), pp. 5-26, https://doi.org/10.1515/cer-2016-0027

Lakner, C., Mahler, D.G., Negre, M., Prydz, E.B. (2019), How Much Does Reducing Inequality Matter for Global Poverty?, "Policy Research Working Paper”, 8869, https:// doi.org/10.1596/1813-9450-8869

Libanova, E.M. (2014), Inequality In Ukraine's Society: Sources And Modernity, “Economics of Ukraine", 3 (628), pp. 4-18.

Meeting of the OECD Council at Ministerial Level, Paris, 7-8 June 2017, Update Report 2017 - Inclusive Growth, https://www.oecd.org/mcm/ministerial-council-meeting -2017.htm (accessed: 5.03.2020).

Minfin systematizes information for the Foundation for the fight against COVID-19, https://www.mof.gov.ua/uk/data_and_analytics-433 (accessed: 3.08.2020).

National Bank of Ukraine (2020), Money transfers to Ukraine (through official and unofficial channels of receipt), https://bank.gov.ua/ua/statistic/sector-external (accessed: 3.08.2020).

OECD (2020a), Employment Outlook 2020: Worker Security and the COVID-19 Crisis, OECD Publishing, Paris.

OECD (2020b), Evaluating the initial impact of COVID-19 containment measures on economic activity, http://www.oecd.org/coronavirus/policy-responses/evalua ting-the-initial-impact-of-covid-19-containment-measures-on-economic-activity -blf6b68b/\#blocknotes-d7e19 (accessed: 3.08.2020).

OECD (2020c), Paid sick leave to protect income, health and jobs through the COVID-19 crisis, http://www.oecd.org/coronavirus/policy-responses/paid-sick-leave-to -protect-income-health-and-jobs-through-the-covid-19-crisis-a9ela154/ (accessed: 3.08.2020).

OECD Wealth Distribution (2020), Database, https://stats.oecd.org/Index.aspx?Data SetCode=WEALTH (accessed: 3.08.2020).

Organiściak-Krzykowska, A. (2017), The Determinants and the Size of International Migration in Central and Eastern Europe After 2004, "Comparative Economic Research. Central and Eastern Europe”, 20 (4), pp. 159-178, https://doi.org/10.1515 /cer-2017-0033

Shang-Jin, W. (2019), How can digital technology tackle inequality?, The World Economic Forum, https://www.weforum.org/agenda/2019/11/how-can-digital-techno logy-tackle-inequality (accessed: 5.03.2020).

Sidenko, V.R. (2014), New global wikis and pouring into the formation of suspicious values, "Ukrainian Social", 1 (48), pp. 7-21, https://doi.org/10.15407/socium2014.01.007 
State Statistics Service of Ukraine (2018), Accounts of institutional sectors of the economy for 2018, http://ukrstat.gov.ua/operativ/operativ2013/vvp/nrzise/nrzise2018 _u.htm (accessed: 3.08.2020).

The World Bank (2020), PovcalNet, http://iresearch.worldbank.org/PovcalNet/povO nDemand.aspx (accessed: 3.08.2020).

Tokarchuk, T. (2020), Perekazi of labor migrants: current situation and assessment of prospects, Seminar: Practical aspects of the formulation and implementation of monetary policy, https://bank.gov.ua/admin_uploads/article/Transfers_from _migrant_workers_Tokarchuk_2020-06-03.pdf?v=4 (accessed: 3.08.2020).

UN ESCAP (2019), Technology and Inequalities, https://www.unescap.org/sites/defau lt/files/06Chapter4.pdf (accessed: 5.03.2020).

United Nations Development Programme in Ukraine (2019), Global Multidimensional Poverty Index 2019, https://www.ua.undp.org/content/ukraine/uk/home/libra ry/sustainable-development-report/global-multidimensional-poverty-index-2019.html (accessed: 3.08.2020).

United Nations Development Programme (2020), Global Multidimensional Poverty Index 2020: Charting pathways out of multidimensional poverty: Achieving the SDGs, http://hdr.undp.org/sites/default/files/2020_mpi_report_en.pdf (accessed: 3.08.2020).

World Economic Outlook (2020), A Crisis Like no other, an Uncertain Recovery, International Monetary Fund, https://www.imf.org/en/Publications/WEO/Issues/2020 /06/24/WEOUpdateJune2020 (accessed: 3.08.2020).

\section{Sposoby przezwyciężania ubóstwa i nierówności dochodowych w kontekście nowych globalnych wyzwań: najważniejsze wnioski dla Ukrainy}

Artykuł analizuje zagrożenia związane z pogłębianiem się ubóstwa i nierówności dochodowych, które wynikają z globalnych wyzwań związanych ze starzeniem się populacji, utratą miejsc pracy w wyniku kurczących się rynków zbytu, wojnami handlowymi, długotrwałą kwarantanną i przestrzeganiem zasad bezpiecznego dystansowania się ludzi w ramach środków ograniczających rozprzestrzenianie się COVID-19, charakterem zatrudnienia (praca zdalna, czasowe ograniczenie migracji zarobkowej) oraz innymi normami służącymi walce z groźną chorobą zakaźną.

Biorąc pod uwagę fakt, że zapobieganie rozprzestrzenianiu się i lokalizacja niebezpiecznych chorób, ich leczenie i rehabilitacja pacjentów dotykają wszystkie części populacji, mają negatywny wpływ na wszystkie dziedziny życia ludzi, a także przyczyniają się do wzrostu zagrożeń społeczno-ekonomicznych, w tym ubóstwa i nierówności, badanie tego zagadnienia jest niezwykle istotne. Konsekwencje finansowe tych wyzwań dla wielu gospodarstw domowych wyrażają się w spadku dochodów realnych, wzroście kosztów i długów oraz ich niespłacaniu, co generalnie powoduje nagłe ubóstwo i zwiększające się nierówności dochodowe i majątkowe.

Cel artykułu: Zbadanie zagrożenia ubóstwem, w tym nagłego ubóstwa, nierówności dochodowych gospodarstw domowych w sytuacji walki z pandemią COVID-19 oraz wskazanie sposobów ich przezwyciężenia. 
Metody: przegląd literatury naukowej, prezentacja danych statystycznych i badania statystyczne.

Ustalenia i wartość dodana: W wyniku badań przedstawiono listę nowych zagrożeń ubóstwem i nierównościami dochodowymi oraz podsumowano wstępne oceny skutków COVID-19 dla gospodarstw domowych; określono oznaki krótkoterminowych strat; oceniono wypłacalność gospodarstw domowych jako możliwy powód nagłego ubóstwa; dokonano międzykrajowych porównań zagrożenia ubóstwem; przedstawiono system pomocy państwa mający na celu poprawę poziomu życia ludzi w okresie wybuchu nowych niebezpiecznych chorób w UE i na Ukrainie; określono sposoby przezwyciężenia ubóstwa i nierówności dochodowych służące przywróceniu bezpieczeństwa finansowego gospodarstw domowych znajdujących się w trudnej sytuacji finansowej i zapewnieniu rozwoju kapitału ludzkiego.

Słowa kluczowe: finanse gospodarstw domowych, stabilność finansowa, walka z ubóstwem, nierówności, migracje zarobkowe, bezrobocie, pandemia COVID-19, ekonomiczne konsekwencje globalizacji, państwowe wsparcie gospodarstw domowych Łódź, Poland. This article is an open access article distributed under the terms and conditions of the Creative Commons Attribution license CC-BY-NC-ND 4.0 (https://creativecommons.org/licenses/by-nc-nd/4.0/) Received: 2020-10-30; verified: 2021-04-20. Accepted: 2021-05-27 